\title{
Correction to: The Principle of Relatedness
}

César A. Hidalgo, Pierre-Alexandre Balland, Ron Boschma,

Mercedes Delgado, Maryann Feldman, Koen Frenken,

Edward Glaeser, Canfei He, Dieter F. Kogler, Andrea Morrison,

Frank Neffke, David Rigby, Scott Stern, Siqi Zheng, and Shengjun Zhu

\section{Correction to: \\ Chapter "The Principle of Relatedness" \\ in: A. J. Morales et al. (Eds.): Unifying Themes \\ in Complex Systems IX, SPCOM, https://doi.org/10.1007/978-3-319-96661-8_46}

We have become aware that we omitted to cite the work of Feldman, M.P., Audretsch, D.B., 1999. in the fifth paragraph. Now the missing reference has been included in the chapter.

Feldman, M.P., Audretsch, D.B.: Innovation in cities: science-based diversity, specialization, and localized competition. Eur. Econ. Rev. 43, 409-429 (1999). 